\title{
ADAPTACJA PODRĘCZNIKÓW SZKOLNYCH DO POTRZEB UCZNIÓW NIEWIDZĄCYCH - STAN I POSTULATY POZNAWCZO-PRAKTYCZNE
}

\begin{abstract}
Streszczenie: $\mathrm{W}$ artykule omówiono zagadnienie adaptacji podręczników szkolnych do potrzeb uczniów niewidomych w polskim systemie szkolnym. Zdefiniowano pojęcie adaptacji, zaprezentowano standardy tworzenia brajlowskich podręczników, uwarunkowania systemowe tego procesu oraz procedurę udostępniania podręczników uczniom niewidomym. Określono najważniejsze zasady adaptacji materiału treściowego oraz reprezentacji graficznych zawartych w oryginalnych podręcznikach. Na podstawie analiz zaadaptowanych materiałów dydaktycznych sformułowano tezy dotyczące stanu adaptacji podręczników brajlowskich w Polsce oraz postulaty poznawczo-praktyczne.
\end{abstract}

Słowa kluczowe: niewidomi, brajl, adaptacja podręczników, tyflografika, podręczniki szkolne

\section{Wprowadzenie}

Współcześnie w literaturze przedmiotu wyróżnia się dwie główne teoretyczne i metodologiczne perspektywy badań nad podręcznikami szkolnymi: konwencjonalną, w której poddaje się analizie funkcję dydaktyczną podręczników oraz ich merytoryczną poprawność (podręcznik ujmowany jest jako książka dydaktyczna - instrument nauczania wyznaczający aktywność ucznia przez ćwiczenia, polecenia, zadania i informacje do przyswojenia) oraz analityczno-dyskursywną (wiedza zawarta w podręczniku ujmowana jest nie jako reprezentacja rzeczywistości, lecz jako jej konstrukcja, dokonywana poprzez wybór treści służący do reprodukcji politycznego, społecznego i kulturowego porządku) (Zalewska 2009; 2012).

Prezentowane w tym opracowaniu rozważania wpisują się w nurt analiz konwencjonalnych, co wynika $z$ dwóch przyczyn. Po pierwsze $z$ umiejscowienia podręcznika dla uczniów niewidomych w systemie podręczników szkolnych. Jest on bowiem adaptacją istniejącego materiału dydaktycznego - opracowaniem specjalnej struktury zewnętrznej (formy podręcznika) przy zachowaniu struktury wewnętrznej (pojemności informacyjnej) podręcznika oryginalnego. Po drugie ze względu na niedostatek współczesnych refleksji nad formą, strukturą, funkcjami i sposobami wykorzystania podręcznika w edukacji dzieci z dysfunkcją wzroku. Obie te przesłanki ukierunkowują na dokonanie w pierwszej kolejności analiz podręcznika brajlowskiego jako tradycyjnie rozumianego środka dydaktycznego. Jednocześnie ten typ analiz traktowany jest jako wyjściowy do dalszych możliwych 
studiów analityczno-dyskursywnych. Potrzebę podjęcia problematyki podręczników dla uczniów o specjalnych potrzebach edukacyjnych w pracach pedagogicznych zauważyć można w ożywiającej się aktywności badaczy z zakresu pedagogiki specjalnej odnoszącej się do tego pola kształcenia specjalnego (Gajdzica 2014a; Gajdzica 2014b).

\section{Adaptacja podręczników szkolnych do potrzeb uczniów niewidzących - standardy i procedura}

Adaptacja podręczników szkolnych do potrzeb uczniów niewidomych, czyli przystosowanie do odbioru ich treści przy udziale innego kanału poznawczego niż to planowano pierwotnie (przekodowanie treści wzrokowych na treści dostępne dotykowo), nie jest prostą konwersją tekstu drukowanego na znaki alfabetu brajla (Śmiechowska-Petrovskij 2010). Jest to dwufazowy proces: koncepcyjny i wykonawczy. W pierwszej fazie następuje analiza struktury i zawartości treściowej podręcznika. Podejmowane są decyzje o rodzaju modyfikacji poleceń, obiektów graficznych, układu treści. Uwzględnia się przy tym treści merytoryczne, które powinny zostać uczniowi przekazane oraz funkcje dydaktyczne (ćwiczenie umiejętności), które materiał ma pełnić, a także specyfikę percepcji dotykowej oraz spodziewane możliwości odbiorcze ucznia w tym zakresie na danym etapie edukacyjnym (w odniesieniu do progu wrażliwości dotykowej i rozdzielczości zmysłu dotyku; detekcyjnego charakteru poznania dotykowego - obiekt dotykowy musi zostać odszukany w oparciu o przesłanki, co do jego obecności lub umiejscowienia; sekwencyjności - przyrost wiedzy na temat poznawanego obiektu następuje sukcesywnie wraz z badaniem przedmiotu i napływającymi informacjami o poszczególnych jego cechach, które następnie są syntetyzowane w oparciu o ślady pamięciowe; wielkości pola percepcji, a także jego zmienności i nieciągłości związanej z przesuwaniem dłoni).

$\mathrm{W}$ drugiej fazie następuje fizyczne (techniczne) przygotowanie materiału w oparciu o techniki brajlowskie (zastosowanie odpowiedniej notacji: integralnej, matematycznej, fizycznej, chemicznej, muzycznej, zapisu brajlowskiego w języku obcym z uwzględnieniem znaków specyficznych w danym języku) oraz techniki przygotowania grafik dotykowych (tyflografik ${ }^{1}$.

Zagadnienie przygotowywania podręczników i książek pomocniczych dla uczniów niewidomych nie znajduje w literaturze naukowej i metodycznej licznych reprezentacji. Choć dydaktyka specjalna ukierunkowana na zaspokajanie potrzeb edukacyjnych uczniów niewidomych została w ostatnich latach uzupełniona o opracowania prezentujące doświadczenia i rozwiązania metodyczne nauczycieli-praktyków (Chojecka, Magner, Szwedowska, Więckowska 2008; Czerwińska 2008a; Dłuska, Karwowska, Karasińska 2011; Kuczyńska-Kwapisz 2012a, 2012b; Paplińska 2012; Witczak-Nowotna 2010; Żabińska 2011), niewiele jest opracowań podejmujących kwestię strategii adaptacji pomocy dydaktycznych do potrzeb uczniów niewidomych (Czerwińska 2008a; 2008b) oraz analizy podręczników

\footnotetext{
1 Tyflografika dla osób niewidomych definiowana jest jako „graficzne odwzorowanie i przedstawienie rzeczywistości, przy zastosowaniu skali, proporcji i generalizacji, w sposób dostępny dotykowo osobom niewidomym” (Jakubowski 2009, s. 38), czyli „grafika użyteczna dla osoby niewidomej, wykonana w dostępnej mu konwencji i zredagowana w sposób umożliwiający i ułatwiający odczytanie dotykiem przekazywanej grafiką informacji” (Więckowska 2012, s. 57-58).
} 
brajlowskich i ich efektywności jako środków dydaktycznych w edukacji dzieci niewidomych (Kuczyńska-Kwapisz, Wałachowska 200oa; 200ob).

Ów niedostatek może mieć związek ze zmianą i wdrażaniem nowego systemu zapewniania uczniom niewidomym i słabowidzącym dostępu do podręczników szkolnych oraz z rozciągniętym w czasie etapem standaryzowania zasad adaptacji podręczników (wypracowanie standardów adaptacyjnych nastąpiło w 2011 roku).

Nowy system zapewniania uczniom z dysfunkcją wzroku podręczników szkolnych obowiązuje od 2009 roku i dotyczy podręczników do nowej podstawy programowej kształcenia ogólnego (Dz. U. z 2009 r. Nr 4, poz. 17). Ministerstwo Edukacji Narodowej zleca i finansuje adaptacje podręczników zamawianych przez dyrektorów szkół (na podstawie wskazówek nauczycieli), w których kształcą się uczniowie niewidomi. Oznacza to czynny udział nauczycieli uczniów niewidomych w doborze podręcznika szkolnego, wybranego z szerokiej oferty podręczników z otwartego rynku wydawniczego. Proces adaptacji podręczników koordynuje Ośrodek Rozwoju Edukacji, zaś wykonawcami są zespoły adaptacyjne z ośrodków akademickich (w latach 2009-2012 Biuro ds. Osób Niepełnosprawnych Uniwersytetu Warszawskiego oraz Katolicki Uniwersytet Lubelski, od 2013 roku Biuro ds. Osób Niepełnosprawnych Uniwersytetu Warszawskiego).

Wdrażanie nowego systemu udostępniania podręczników do potrzeb uczniów niewidomych pociągnęło za sobą konieczność ujednolicenia strategii adaptacyjnych. Scentralizowanie i ujednolicenie zasad adaptacji rozwiązało problem przygotowywania podręczników dla dzieci z dysfunkcją wzroku przez różne ośrodki w oparciu o alternatywne, różniące się zasady. W ramach prac zespołu eksperckiego scalającego różne środowiska działające na rzecz niewidomych i słabowidzących wypracowano dokumenty organizujące i kodyfikujące proces powstawania podręczników w brajlu i w powiększonym druku, rekomendowane przez Ministerstwo Edukacji Narodowej. Należą do nich:

- Zasady adaptacji materiałów dydaktycznych do potrzeb osób słabowidzacych (Kończyk 2011);

- Zasady adaptacji materiałów dydaktycznych do wersji brajlowskiej (Wdówik 2011);

- Instrukcja tworzenia i adaptowania ilustracji i materiałów tyflograficznych dla uczniów niewidomych, opracowana na zlecenie Departamentu Zwiększania Szans Edukacyjnych Ministerstwa Edukacji Narodowej przez zespół tyflopedagogów ze specjalnych Ośrodków Szkolno-Wychowawczych dla Niewidomych i Słabo Widzących w Polsce, redagowana przez s. E. Więckowską (2011);

- Zasady tworzenia i adaptowania grafiki dla uczniów niewidomych, opracowane przez nauczycieli Specjalnych Ośrodków Szkolno-Wychowawczych dla Niewidomych i Słabo Widzących w Polsce (2011);

- Brajlowska notacja matematyczna fizyczna chemiczna (Kauba 2011).

Materiałem uzupełniającym powyższe dokumenty są również Standardy tworzenia oraz adaptowania map i atlasów dla niewidomych uczniów, opracowane przez A. Chojecką, B. Hermanowicz, C. Fuksińskiego, J. Mendrunia, M. Olczyk, M. Rudnicką, s. E. Więckowską, redagowane przez s. E. Więckowską (2012).

Aktualnie zaadaptowanych jest łącznie 370 podręczników brajlowskich do różnych etapów edukacyjnych. Procedura procesu adaptacyjnego opiera się na zasadzie zachowania treści merytorycznych podręcznika oryginalnego (podlegającego prawu autorskiemu) przy zastosowaniu rozwiązań formalnych udostępniających te treści oraz umożliwiających 
największą samodzielność ucznia w zakresie wykonywania poleceń i ćwiczeń. Szczegółowy zestaw procedur określających sposoby modyfikacji materiału drukowanego zawierają Zasady adaptacji materiałów dydaktycznych do wersji brajlowskiej (Wdówik 2011). Poniżej omówiono niektóre z nich.

Każdy zaadaptowany podręcznik zawiera treści oryginalne (autorskie) oraz dodatkowe komentarze objaśniające, pochodzące od adaptatora. W związku z tym publikacja w brajlu uzupełniona jest o listę uwag do wersji brajlowskiej, znajdującą się na początku każdego tomu podręcznika ${ }^{2}$, objaśniających zastosowane w nim rozwiązania. Przykładowe uwagi do wersji brajlowskiej:

Wybrane ilustracje zostały przygotowane w postaci grafiki dotykowej. O położeniu grafiki każdorazowo informuje odpowiedni komentarz.

W podręczniku zwykłym na marginesach znajdują się hasła informujące o zawartości akapitu, oznaczone zieloną kropką. W brajlu hasła te zapisano w nawiasach kwadratowych przed odpowiednim akapitem.

Ramki w kolorze żółtym oznaczono znakami [2356] oraz wyrazem „żółty” w górnej krawędzi ramki.

Oprócz uwag do wersji brajlowskiej, będących wyodrębnioną częścią tomu, odnoszących się do globalnych rozwiązań zastosowanych w podręczniku, w adaptacjach znajdują się również uwagi umieszczone w treści podręcznika przed lub po fragmencie, do którego się odnoszą, np.:

Cyfry podkreślone pojedynczą linią zapisano w nawiasach kwadratowych, a podkreślone podwójną linią w nawiasach klamrowych.

Innowacyjnym rozwiązaniem dotyczącym brajlowskiego formatowania poleceń i zadań z podpunktami, których celem jest ułatwienie lokalizowania punktów oraz ujmowanie relacji podrzędności między jednostkami tekstowymi, jest zastosowanie systemu wysunięć i wcięć linii tekstu. Początki akapitów (zadań, podpunktów) przysuwane są do lewego marginesu, czyli pierwszy wiersz jest wysunięty, natomiast złamany akapit (tekst przeniesiony do nowej linii) - wcięty. Z kolei podpunkty danego zadania (teksty pozostające w relacji podrzędności), choć formatowane są według tej samej zasady, to są odsunięte od lewego marginesu o oznaczoną liczbę pustych znaków i łamane również z większym wcięciem. Jest to znacząca zmiana w stosunku do dotychczasowej praktyki stosowania standardowego wcięcia akapitowego, które wykorzystuje się teraz tylko w przypadku translacji tekstów w oryginale złożonych w ten sam sposób.

\footnotetext{
2 Ze względu na objętość publikacji brajlowskich książki dzielone są na części, które nie powinny być większe niż 60 kartek brajlowskich. Przykładowo 352-stronicowy podręcznik do historii dla szkół ponadgimnazjalnych mieści się w 17 tomach brajlowskich, po około 100 stron każdy, co daje ponad 1700 stron brajlowskich.
} 
Ten sposób rozkładania treści na stronie zwiększa jej czytelność - przesuwając dłonie w poszukiwaniu zadania lub polecenia wzdłuż lewego marginesu, osoba niewidoma natrafi na linie wysunięte i wcięte, dzięki którym w łatwy sposób będzie mogła zarówno odnaleźć poszukiwane treści, jak i uchwycić hierarchię tekstu.

W adaptacjach podręczników do brajla unika się ingerencji w treść poleceń, z wyjątkiem uzasadnionych sytuacji ukierunkowanych na zwiększenie samodzielności ucznia, np. poprzez zmianę czynności wykonawczej odnoszącej się do wykorzystania kanału wzrokowego (zamiast „podkreśl” - „wypisz”, „połącz” - „zapisz w parach”). Przeredagowanie treści zadania oraz zastosowane formatowanie tekstu brajlowskiego nie może sugerować uczniowi odpowiedzi lub rozwiązania.

W celu ułatwienia wyodrębniania ważnych informacji stosuje się również zróżnicowanie formatowania nagłówków, a także wprowadza się specjalne linie wydzielające złożone ze zróżnicowanych typów znaków bazujących na sześciopunkcie brajlowskim, które tworzą ramki ujmujące wydzielone w oryginale partie tekstu.

Osobna grupa reguł odnosi się do elementów, które w oryginalnym podręczniku umieszczone były w obszarze marginesu książki, pozostających w rozmaitym związku z tekstem głównym (wyjaśnienia trudnych słów, syntezy rozdziału w podpunktach, przypisy do tekstu i inne). Muszą one zostać włączone w blok tekstu po uprzednim określeniu kolejności pojawiania się tych informacji oraz sposobu ich wydzielenia.

Treści prezentowane $\mathrm{w}$ tabelach $\mathrm{w}$ brajlu mogą być odzwierciedlone również $\mathrm{w}$ tabelach (skodyfikowano rodzaj linii pionowych i poziomych tworzonych przez znaki brajlowskie). Stosowane rozwiązania w przypadku dużych tabel to m.in. zamiana kolumn i wierszy, podział tabeli oryginalnej na kilka części, wybór układu schodkowego tabeli (system wysunięć i wcięć - elementy danego wiersza tabeli prezentowane są jeden pod drugim, kolumna po kolumnie, z zastosowaniem wcięć, następnie ta struktura przestrzenna powtarzana jest dla kolejnego wiersza tabeli). Niekiedy stosuje się również format liniowy dla tabel, treści wydzielając z poszczególnych komórek wybranym separatorem, np. średnikiem, informując uprzednio o zastosowanej formule. Innym systemem pozwalającym na ukazanie przestrzennego rozmieszczenia treści w tabeli jest umieszczenie dotykowej tabeli (linie budowane przez znaki brajlowskie) zawierającej w komórkach tylko kody (np. liczby i litery), natomiast jej zawartość umieszczana jest poniżej z przyporządkowanym kodem do danej jednostki tekstowej. W niektórych przypadkach możliwe jest również przygotowanie tabeli w postaci grafiki dotykowej, w której linie nie są budowane ze znaków brajlowskich, lecz mają charakter ciągły.

W adaptacjach brajlowskich nie pomija się także krzyżówek i logogryfów. Aby uczniowi umożliwić właściwe dobranie rozwiązania do zapytania oraz odtworzenie hasła - rozwiązania całej krzyżówki, w odpowiedniej uwadze do wersji brajlowskiej podaje informację o liczbie liter, z których składa się odpowiedź oraz pozycję litery, która następnie posłuży do utworzenia hasła - rozwiązania. Stosuje się różne sposoby adaptacji krzyżówek, w tym między innymi, w przypadku krótszych krzyżówek, udostępnia się je w postaci grafiki dotykowej.

W adaptacjach nie unika się wykorzystywania elementów dotyczących kolorystyki tekstu, pól, ramek, cech formatowania czcionki (pogrubienia, podkreślenia, rozstrzelenia, kapitalików, wersalików, innych rodzajów druku), pod warunkiem, że są to informacje istotne z punktu widzenia przekazu treści (wyróżnienia jakiegoś fragmentu tekstu/ 
wyrazów czy odróżnienia go od innych fragmentów) i wykonania polecenia. W tym celu stosuje się system oznaczeń dostępnych dla ucznia niewidomego w postaci brajlowskich znaków wyróżnionej czcionki, wydzielenia tekstu nawiasami, zastosowania odpowiednich kodów kolorystycznych.

Elementy graficzne, które są zawarte w oryginalnych podręcznikach są udostępniane - w zależności od funkcji, jaką pełnią w podręczniku oraz stopnia ich skomplikowania formalnego - za pomocą opisu słownego (najczęściej opis stosowany jest w przypadku reprodukcji dzieł sztuki, fotografii, ilustracji, obrazków) lub grafiki dotykowej (najczęściej są to adaptacje tyflograficzne map geograficznych i historycznych, planów - budynków, pomieszczeń, terenu; diagramów, schematów, przekrojów, wykresów oraz rysunków matematycznych, fizycznych, i chemicznych i z zakresu biologii).

Pomijane są te reprezentacje graficzne, których celem jest jedynie wizualne uatrakcyjnienie podręcznika albo które niosą informacje zawarte już w tekście lub podpisie ilustracji.

W sytuacji, w której nie jest możliwe zaadaptowanie elementu graficznego do formy dotykowej, reprezentacja graficzna zastępowana jest opisem słownym. Opisy słowne występujące w podręcznikach brajlowskich należy podzielić na takie, które:

- służą dostarczeniu krótkiej, konkretnej informacji o składowych ilustracji, bez dodatkowej deskrypcji (np. przy poleceniu „Podpisz atrakcje turystyczne polskich pojezierzy” zamiast zdjęć, znajdują się zapisy: „fotografia A: pomost na jeziorze, piaszczysta plaża, wypoczywający ludzie; fotografia B: las; kobieta i dziewczynka z koszem pełnym grzybów; fotografia C: żaglówki na jeziorze");

- zawierają szczegółowe informacje o cechach wizualnych obiektów (np. opisy flag lub herbów, do których uczeń ma dopasować nazwy państw i miast);

- prezentują dzieła sztuk plastycznych.

Reprezentacje graficzne w adaptowanych podręcznikach umożliwiają rozwiązywanie zadań i przyswajanie treści przewidzianych w programie nauczania. Na przykład na podstawie zdjęć osób w strojach ludowych zadaniem ucznia jest rozpoznanie, z jakich regionów kulturowych Polski one pochodzą. Przykładowy opis jednego ze zdjęć:

Fotografia B: Dziewczynka: wianek z barwnymi wstążkami; biała koszula zdobiona haftem krzyżykowym; gorset ozdobiony kolorowymi tasiemkami, cekinami, koralikami; gęsto marszczona spódnica z naszyciami z barwnych tasiemek; na spódnicy krótka, marszczona, kolorowa zapaska; czarne, wysokie trzewiki, sznurowane tasiemką. Chłopiec: słomiany kapelusz ozdobiony wstążką oraz czerwonym i zielonym sznurkiem; wykładana na spodnie biała koszula, z haftem na kołnierzyku; kolorowy, szeroki pas; krótki, czarny kaftan zdobiony pasami z wycinanymi kolorowymi okienkami; ciemne spodnie o prostym kroju wpuszczone w cholewy wysokich, skórzanych butów ${ }^{3}$.

W podręcznikach z zakresu kształcenia literacko-kulturowego często pojawiają się problemowe polecenia odnoszące się do różnych tekstów kultury, np. zadaniem ucznia jest

\footnotetext{
${ }^{3}$ Opis ilustracji z adaptacji zeszytu ćwiczeń Przyrodo, witaj! 5, E. Gromek, E. Kłos, W. Kofta, E. Laskowska, A. Mekson, WSiP 2013.
} 
wybranie jednego z pięciu obrazów Jana Matejki i opowiedzenie o nim w odniesieniu do zdobytej uprzednio wiedzy oraz określenie, co przedstawia dzieło i w jaki sposób, co znajduje się na pierwszym, drugim planie, co zwraca uwagę odbiorcy, z jakimi wydarzeniami kojarzą się przedstawione sceny. W tak zaplanowanej sytuacji dydaktycznej szczególnie trudne jest przygotowanie opisów obrazów, które z jednej strony będą dostarczać potrzebnych uczniowi informacji na temat zawartości treściowej dzieła, relacji przestrzennych pomiędzy elementami przedstawienia, techniki wykonania i wizualnych środków artystycznego wyrazu, ale jednocześnie nie będą wyręczać go w zakresie wykonania zadania oraz nie będą wyznaczać horyzontu interpretacyjnego dzieła.

Jeśli chodzi o grafikę dotykową, to w licznych fachowych opracowaniach (Bendych 1994, 1995; Chojecka, Magner, Szwedowska, Więckowska 2008; Czerwińska 2008; Więckowska 2012) podkreśla się, że tyflografika jest wartościowa dla ucznia niewidomego wtedy, gdy jest dla niego użyteczna - przekazuje informacje o pojęciach przestrzennych (pojęcia geometryczne i z zakresu orientacji), o kształtach przedmiotów (widok, rzut, rzuty, przekrój), o relacjach przestrzennych między przedmiotami (plan, mapa). Najistotniejszą trudnością w czytaniu grafiki u osób z dysfunkcją wzroku jest bowiem brak oczywistego związku między obrazem graficznym a obiektem rzeczywistym. Brak podobieństwa między formą przedstawiającą a przedstawianą $z$ uwagi na specyfikę poznania dotykowego wyznacza inną rolę reprezentacjom tyflograficznym - mają one opowiadać niewidomemu o przedmiocie, stąd nie każda konwencja rysunkowa będzie użyteczna. Wśród dostępnych konwencji wymienia się: rysunek geometryczny przedstawiający figury płaskie oraz rysunek konstrukcyjny na płaszczyźnie; rysunek ilustracyjny w konwencji rzutu prostokątnego (widok) wykonany bez niepotrzebnych szczegółów; rzut przedmiotu na jedną, dwie i trzy płaszczyzny; scena (rysunek kilku obiektów umieszczonych tak, że nie zasłaniają jeden drugiego; rysunek przedmiotu w przekroju; plan pomieszczenia, budynku, terenu, miasta; mapa w dowolnej skali i o odpowiednim poziomie uogólnienia; wykres zależności funkcyjnej; diagram; rysunek wektorowy, schemat elektryczny, schemat komunikacyjny itp.) Ponadto nie jest rekomendowane tworzenie dotykowych reprezentacji graficznych służących ukazywaniu nieprzestrzennych związków między pojęciami, jak związki logiczne, przyczynowe i organizacyjne, które powinno się obrazować objaśnieniem słownym, numeracją dziesiętną lub w inny funkcjonalny sposób (Zasady tworzenia i adaptowania grafiki dla uczniów niewidomych 2011; Instrukcja tworzenia i adaptowania ilustracji i materiałów tyflograficznych dla uczniów niewidomych 2011; Więckowska 2012).

Tyflografika powinna być czytelna, a zatem wypukłe linie, kształty, znaki, punkty i faktury muszą być odpowiednio wysklepione, by osoba normalnie funkcjonująca dotykowo, mogła je odróżnić i zidentyfikować. Należy także zachować odpowiednie odległości między elementami wypukłymi, by były postrzegane jako różne, natomiast faktury taktylne zastępujące kolor (gęsto rozmieszczone, jednakowe, drobne wypukłe detale) powinny być przygotowane w taki sposób, by czytelnik nie rozpoznawał komponentów, lecz postrzegał całość jako obszar innego typu - różny od sąsiadujących. Ważne jest także, by stosować odpowiednio zróżnicowane linie wypukłe, aby można było odróżnić te, które oznaczają np. granicę państwa na mapie, od rzeki lub równoleżnika. Dobrze przygotowana grafika dotykowa zawiera, oprócz wypukłych elementów graficznych, również niezbędne słowne objaśnienia w postaci tytułów, podpisów, etykiet brajlowskich, legendy przybliżającej zastosowany system skrótów (stosowany konsekwentnie na rysunku i w objaśnieniu) 
(Zasady tworzenia i adaptowania grafiki dla uczniów niewidomych 2011; Instrukcja tworzenia i adaptowania ilustracji i materiałów tyflograficznych dla uczniów niewidomych 2011; Więckowska 2012).

Zgodnie z Instrukcją tworzenia i adaptowania ilustracji i materiałów tyflograficznych dla uczniów niewidomych (2011) oraz Zasadami tworzenia i adaptowania grafiki dla uczniów niewidomych (2011) adaptacja treści reprezentacji graficznej może polegać na zmianie konwencji, czyli sposobu przedstawiania, zmianie skali (powiększenie obrazu), zmianie poziomu generalizacji (uszczegółowienia) - zrezygnowanie z mniej istotnych treści, które mogą spowodować, że rysunek będzie nieczytelny, podziale rysunku na kilka części (np. podział treści mapy na kilka map), zmianie linii, znaków i kolorów na zróżnicowane dotykowo linie i faktury, uproszczeniu rysunku i uzupełnieniu usuniętych elementów opisem słownym.

Po zaadaptowaniu treści grafiki następuje etap jej uwypuklenia, czyli zastosowania odpowiedniej techniki wytworzenia rysunku wypukłego. Do najbardziej cenionych technik zalicza się technikę eksplozyjną (na tzw. papierze puchnącym), formowania termoplastycznego, termografii, wydruku na drukarce brajlowskiej.

\section{Adaptacja podręczników szkolnych do potrzeb uczniów niewidzących - stan i postulaty poznawczo-praktyczne}

Analiza podręczników brajlowskich z zakresu języka polskiego (kształcenia literacko-kulturowego i językowego), wiedzy o społeczeństwie, historii, języków obcych (angielskiego, rosyjskiego, niemieckiego), matematyki, fizyki, chemii, przyrody, biologii, geografii, muzyki, techniki prac biurowych, religii (dla II, III i IV etapu edukacyjnego) oraz z zakresu edukacji wczesnoszkolnej, a także innych dydaktycznych materiałów pomocniczych, pozwala na sformułowanie następujących tez dotyczących adaptacji podręczników szkolnych do potrzeb uczniów niewidomych w Polsce:

\section{Podręczniki dla uczniów niewidzących są użyteczne}

we wszystkich formach kształcenia: segregacyjnym, integracyjnym i inkluzyjnym.

Podejście do podręczników brajlowskich wyrażone w zasadach ich adaptacji oraz w konkretnych realizacjach ukazuje dbałość o użyteczność materiałów dydaktycznych dla uczniów niewidomych we wszystkich formach kształcenia: segregacyjnym, integracyjnym i inkluzyjnym. Strategie umożliwiające włączanie ucznia niewidomego do zwykłych sytuacji dydaktycznych w szkołach ogólnodostępnych to przede wszystkim zachowanie wszystkich treści merytorycznych podręcznika (zamiast tworzenia wyłącznie jego wersji tekstowej z pomijaniem fragmentów wymagających znaczących modyfikacji). Ponadto do tych strategii należy zaliczyć między innymi zachowanie podwójnej numeracji stron - oryginalnej oraz numerów stron wersji brajlowskiej, co pozwala osobie niewidomej korzystać z podręcznika według wskazówek nauczyciela skierowanych do całej klasy uczniów, a nie osobno do niego. Podwójna numeracja umożliwia także tworzenie odnośników do cytatów z podręcznika (wskazanie numeru stron oryginału) oraz ułatwia nawigację po książce osobom widzącym, wspomagającym ucznia (rodzicom, nauczycielom). Oprócz tego ukierunkowanie na zachowanie w podręczniku adaptowanym informacji na temat zdjęć, 
wykresów, rysunków, tabel, ramek, wyróżnień tłem, kolorem, wielkością i innymi parametrami czcionki, a także sposobów numerowania rozdziałów i podrozdziałów, poleceń czy zadań ułatwia uczniowi adekwatne reagowanie na polecenia typu „znajdź w ramce”, „na żółtym tle umieszczono...” itp., które mają miejsce w pracy w grupach mieszanych.

Podręczniki zaadaptowane do brajla wspierają edukację tyflograficzną uczniów niewidzących.

Niewątpliwą zaletą tworzonych współcześnie podręczników dla dzieci niewidomych jest uzupełnienie ich o rysunki dotykowe. Umiejętność rozumienia informacji zawartych w formie graficznej (oddawana w literaturze anglojęzycznej terminem graphicacy) - szkiców, zdjęć, wykresów, map, planów, diagramów i innych dwuwymiarowych formatów - jest istotną kompetencją współczesnego człowieka (Aldrich, Sheppard 200o). Graphicacy zakłada również umiejętność prezentowania informacji w wymienionych powyżej formach. Przekazywane informacje mogą mieć postać bezpośrednich przedstawień tego, co ujmuje zmysł wzroku (zdjęcia, rysunki, ilustracje) lub abstrakcyjnych ujęć (informacji przestrzennych - mapy, plany; numerycznych - tabele, wykresy). Osiągnięcie pewnego poziomu graphicacy jest wymagane we współczesnym świecie, o czym świadczy powszechne stosowanie graficznych przedstawień w mediach, ulotkach, broszurach i oczywiście materiałach dydaktycznych, a także - podczas sprawdzianów i egzaminów państwowych.

Choć, jak zauważono wcześniej, nie wszystkie konwencje graficzne są dostępne dla dzieci niewidomych, a także niezbędne jest prowadzenie metodycznego nauczania uczniów niewidzących czytania grafiki wypukłej, by mogły z niej skutecznie korzystać, tyflografika zawarta w podręcznikach brajlowskich może wspierać ten proces. Jeśli będzie dobrze zredagowana i przygotowana w różnorodny sposób, zwielokrotni i zróżnicuje doświadczenia dzieci z grafiką dotykową (zapoznawanie się z konwencjami przedstawieniowymi oraz technikami).

Tyflografika w podręcznikach dla dzieci niewidomych z pewnością pełni też funkcję uatrakcyjnienia przekazu. Uatrakcyjnienie treści, idące w parze z użytecznością rysunku dotykowego, pozwala na zanegowanie sytuacji, która do niedawna miała miejsce w kształceniu osób niewidomych, a która sugestywnie została wyrażona w przytoczonej przez Kornelia Czerwińską (2006) wypowiedzi nauczyciela ze szkoły specjalnej: „Proszę zobaczyć na podręczniki w brajlu do nauczania zintegrowanego - „Moja szkoła” do pierwszej klasy - ile jest tutaj rysunków? Całość podręcznika to 10 tomów pisanych dwustronnym brajlem. W pierwszym tomie znalazłam jeden rysunek przedstawiający figury geometryczne i rysunki znaków drogowych. A gdyby wziąć ten sam podręcznik dla dziecka prawidłowo widzącego, rysunków, na których opierają się ćwiczenia, byłoby mnóstwo. Na naszym obecnym etapie kształcenia generalnie niewidomi są oddzieleni od świata obrazu" (Czerwińska 2006, s. 327).

Z dociekań badawczych i doniesień z praktyki edukacyjnej wynika, że choć uczniowie niewidomi nie mają wysokich kompetencji w zakresie korzystania z tyflografiki (liczne postulaty formułowane na gruncie literatury fachowej oraz projekty edukacyjne, realizowane zwłaszcza w szkolnictwie specjalnym, ukierunkowane są na poprawę tej sytuacji poprzez wczesną edukację tyflograficzną prowadzoną według dobrze opracowanych wskazówek metodycznych), to można odnotować raczej pozytywny stosunek niewidzących użytkowników 
książki do taktylnych reprezentacji graficznych. Interesujących informacji dostarczają doniesienia z badań zagranicznych. Studia Ki t. Zebehazy’ego i Adama P. Wiltona (2014) wskazują, że uczniowie niewidomi kształcący się na różnych poziomach edukacyjnych ${ }^{4}$ wyrażają zadowolenie, gdy mają dostęp do grafiki dotykowej (84\%) i chcieliby by był on większy (52\%). Korzystają najczęściej z grafiki dotykowej podczas zajęć matematycznych (91\%) oraz z zakresu innych nauk ścisłych (86\%), podczas lekcji z przedmiotów z obszaru nauk społecznych - wskazań udzieliło 70\% badanych, a z języka i literatury - 19\%. W percepcji użytkowników grafika dotykowa jest pomocna w przyswajaniu treści matematycznych i z innych przedmiotów ścisłych, ponadto pomaga zrozumieć, co się dzieje w klasie szkolnej (np. co jest prezentowane na tablicy lub o czym nauczyciel mówi) oraz jest przydatna w zrozumieniu niektórych pojęć przestrzennych. Badacze sugerują, że entuzjazm uczniów związany z użytkowaniem grafiki dotykowej może częściowo wynikać z uczuć włączenia. Mimo iż mniej niż połowa użytkowników (47\%) twierdziła, że udaje jej się nadążać za rówieśnikami podczas wykorzystywania grafiki dotykowej w trakcie wykonywania lekcyjnych zadań, to dostęp do tyflografiki pomaga im zrozumieć, co się dzieje w klasie i być lepiej włączonym we wspólne aktywności (Zebehazy, Wilton 2014).

W polskich podręcznikach brajlowskich grafika dotykowa ma najliczniejszą reprezentację w zakresie matematyki, fizyki, chemii i biologii (figury geometryczne, wykresy funkcji, wykresy statystyczne, schematy elektryczne, przekroje struktur organizmów, schematy budowy różnych układów, modele cząsteczek, jonów) oraz geografii i historii (mapy, plany, wykresy, diagramy). W zakresie języka polskiego najczęściej adaptacji tyflograficznej podlegają schematy zdań, plany budynków, miast, sceny. We wszystkich tych podręcznikach, jako element grafiki dotykowej, występują również krzyżówki i logogryfy.

\section{Reprezentacje graficzne w podręcznikach szkolnych zawierają niezbędną obudowę słowną.}

Ważnym warunkiem efektywnego wykorzystania grafiki dotykowej w podręcznikach szkolnych jest ich obudowa słowna (Więckowska 2012), czyli tytuły, podpisy rysunków wypukłych, legenda objaśniająca użyte symbole, linie, faktury i skróty, podpisy elementów rysunku (etykiety). Walorem polskich adaptacji podręczników jest uwzględnianie niezbędnej słownej obudowy prezentowanych obiektów dotykowych. Grafiki dotykowe znajdują się wraz ze opisem na osobnej stronie lub stronach brajlowskich podręcznika. Są zorientowane tj. zawierają wskaźnik orientacji strony (wypukły trójkąt umieszczony w prawym górnym - dalszym - rogu kartki lub informacja o tym, że podręcznik należy obrócić np. o go stopni w prawo), co pozwala uczniowi na odpowiednie ułożenie materiału przed sobą.

W ewaluacji grafik w podręcznikach szkolnych dla niewidomych zwraca się uwagę na następujące elementy: faktury, symbole, linie, punkty użyte w legendzie powinny być dokładnie takie same na mapach pod względem orientacji, wzoru i rozmiaru (wertykalnie, horyzontalnie, diagonalnie). Podobnie rzecz się ma ze stosowanymi skrótami zamieszczonymi w legendzie i ich identycznością na etykietach w grafice. Polskie adaptacje podręczników szkolnych należy dobrze ocenić pod tym względem.

\footnotetext{
4 Próba 64 uczniów w wieku 9-18 lat, użytkowników grafiki dotykowej.
} 
Grafika dotykowa wykorzystywana w adaptacjach podręczników nie jest badana pod względem jej czytelności przez dzieci niewidzące.

W piśmiennictwie fachowym zwraca się uwagę na konieczność dotykowej korekty tyflografiki w podręcznikach brajlowskich. Wiąże się to z faktem, iż współcześnie ilustracje dotykowe powstają w programach graficznych na ekranie komputera, wykonywane przez widzącego grafika. Aby więc zapewnić ich komunikatywność dla osoby niewidomej, niezbędna jest weryfikacja prototypu tyflograficznego, wykonanego w wybranej technice. Robyn O’Day (2014) postuluje dwie korekty grafiki dotykowej: pierwszą, dokonywaną przez osobę przygotowującą ilustracje dotykowe w celu określenia, czy najważniejsze informacje zawarte na oryginalnej reprezentacji graficznej zostały uwzględnione $\mathrm{w}$ tyflografice, oraz drugą, dokonywaną dotykiem przez wyspecjalizowanego brajlistę, w celu sprawdzenia taktylnego zróżnicowania elementów ilustracji oraz zrozumiałości reprezentacji (czytelności rysunku - rozmiary elementów i odległości w pliku komputerowym dają tylko orientacyjną wiedzę o tych parametrach w druku wypukłym). Taka korekta powinna być dokonywana na wydruku próbnym w konkretnej technice (ta sama grafika będzie inaczej odbierana dotykiem po przetworzeniu w różnych technikach). Istotne jest, żeby korektor brajlowski miał wiedzę o tym, co jest przedstawiane na rysunku wypukłym, by mógł stwierdzić, czy jakieś błędne informacje nie zostały dodane, lub czy coś nie zostało pominięte. W polskich Zasadach tworzenia i adaptowania grafiki dla uczniów niewidomych (2011) etapy przygotowania tyflografiki zostały uzupełnione jeszcze dalej idącym wymogiem w zakresie korekty tyflograficznej. Zakłada się następujący porządek postępowania adaptacyjnego:

1) Adaptator powinien nie tylko ustalić tytuł, ale przede wszystkim zdać sobie sprawę, jakie informacje grafika ma przekazać niewidomemu czytelnikowi.

2) Powinien ustalić poziom generalizacji.

3) Powinien, znając powyższe zasady, ustalić skalę i rozmiar prezentacji oraz orientację arkusza, a następnie narysować projekt reprezentacji ołówkiem na papierze lub w komputerze.

4) Na etapie projektu adaptator powinien sam, lub z pomocą tyflologa dokonać korekty - zastanowić się, czy zachowane są istotne zasady redakcji i zasadnicze przesłanie prezentacji graficznej.

5) Następnie należy dokonać przetworzenia grafiki do postaci docelowej w tej technice, która jest przewidziana do dalszego tworzenia danej prezentacji.

6) Przetworzona wersja próbna powinna być poddana korekcie osób niewidomych i słabowidzących reprezentujących przyszłych adresatów prezentacji. Korekcie takiej powinna być poddana także warstwa słowna informacji, jeśli ma towarzyszyć prezentacji graficznej. Korektę grafiki dla początkujących powinien przeprowadzać tyflopedagog nauczania początkowego (pogrubienie - E. S.-P.).

7) Po pozytywnym wyniku takiej korekty lub po wprowadzeniu potrzebnych poprawek prezentacja może być wytwarzana i rozpowszechniana wśród właściwej grupy czytelników.

Postulowana korekta przetworzonej wersji ilustracji dotykowych z pomocą grupy niewidomych jest ważnym standardem, który jednak nie jest współcześnie realizowany w procesie adaptacji podręczników szkolnych do potrzeb uczniów niewidomych. Słabością 
polskich podręczników brajlowskich jest to, że nie są one poddawane ocenie pod względem czytelności tyflograficznej przez uczniów niewidomych - odbiorców treści (wszystkie podręczniki brajlowskie zawierają adnotację określającą, że grafika dotykowa wykorzystana $\mathrm{w}$ danym podręczniku nie była badana przez dzieci niewidome). Mimo interindywidualnego zróżnicowania uczniów niewidzących pod względem dotykowego funkcjonowania, które może być argumentem na rzecz braku podobnych badań (to, co dla danego ucznia będzie optymalne, dla innego - ze względu na zróżnicowane przygotowanie w zakresie czytania rysunku dotykowego - może być niezrozumiałe), bezwzględnie zasadne jest rekomendowanie testowania ilustracji wypukłych nawet na niewielkiej próbie uczniów niewidomych. Pozwoli to uzyskać ważną informację zwrotną na temat stopnia ich użyteczności i komunikatywności, ale także na temat kompetencji samych uczniów, co może wesprzeć metodykę edukacji tyflograficznej.

\section{Grafika dotykowa wykorzystywana w adaptacjach podręczników nie jest oferowana w zróżnicowanych technikach.}

Kolejną kwestią jest zróżnicowanie technik, w jakich tworzone są grafiki dotykowe. Jak wspominano wcześniej, współcześnie do najbardziej wartościowych technik tworzenia grafiki dotykowej do materiałów dydaktycznych (a zatem uwzględniających możliwości łatwej reprodukcji) są techniki: eksplozyjna, formowania termoplastycznego, termografii i wydruku na drukarce brajlowskiej.

W polskich adaptacjach podręczników szkolnych dominują grafiki dotykowe wydrukowane na drukarce Tiger. Drukarka umożliwia zastosowanie gradacji linii i faktury rysunku w oparciu o plik przygotowany w grafice wektorowej lub rastrowej. Do wydruku wykorzystywany jest zwykły papier brajlowski, co znacząco obniża koszt produkcji. System ten umożliwia precyzyjne przygotowanie rysunków skonstruowanych z linii krzywych i w oparciu o różnicowanie faktur. Wskazuje się jednak, że dostępne w tej technice różnicowanie faktur nie zawsze pozwala niewidomym na efektywne korzystanie $\mathrm{z}$ bardziej skomplikowanych reprezentacji dotykowych zawierających dużą liczbę linii, tekstur, punktów, etykiet - np. w szczegółowych mapach. Innymi słowy grafiki drukowane na drukarce Tiger nadają się do prostszych rysunków z małą zawartością treści (Talukder 2010). Ponadto obraz tworzony jest z pojedynczych punktów wybijanych przez cienkie igiełki, w związku z tym nie sposób uzyskać linii ciągłych - skosy i zaokrąglenia mają specyficzny „poszarpany” walor. Dodatkowo wydruki taktylne na drukarce Tiger tworzone są przez ostre punkty, które nie są wygodne do dłuższego czytania. Ponieważ ogólnie czynnikiem hamującym przydatność grafiki dla uczniów niewidomych w zakresie rozumienia niektórych pojęć jest złożoność rysunków wypukłych (np. adaptacja map, rysunki ze zbyt dużą liczbą szczegółów) (Zebehazy, Wilton 2014), to dodatkowe przygotowanie ich w oparciu o technikę zwiększającą odczucie złożoności i nieprzyjazności dotykowej może skutkować niechęcią do korzystania z niej i brakiem komunikatywności, a zatem przydatności dla odbiorcy. Mimo więc wielu zalet tej techniki przygotowania wypukłych ilustracji, zasadne jest proponowanie uczniom materiałów przygotowywanych w zróżnicowanych technikach, w których najważniejszym kryterium wyboru będzie czytelność i komunikatywność wytworzonego materiału tyflograficznego. Wprawdzie część zaadaptowanych podręczników przygotowywanych na zlecenie MEN uzupełniona została o grafiki dotykowe wykonane 
w technice termografii, ale niestety od 2013 roku technika ta nie jest już używana do tworzenia ilustracji dotykowych do podręczników szkolnych. Termografia wykorzystuje narzędzie zwane termografem, na którego taśmie wilgotny wydruk płaski obsypywany jest przez proszek termograficzny (o specjalnych właściwościach). Następnie w tunelu termograficznym w temperaturze 700 stopni Celsjusza, granulki, które się do niego przykleiły, zaczynają się topić i łączyć ze sobą, tworząc jednolitą formę o chropowatej fakturze. Po schłodzeniu rysunek gotowy jest do eksploracji (Poppe 2006; Matys 2008). Jak wynika z badań K. Czerwińskiej, tyflografiki wykonywane w tej technice oceniane były przez osoby niewidome jako czytelne (ze względu na odpowiednią wysokość wypukłej linii), trwałe i przyjazne dotykowo (Czerwińska 2008), choć właściwością wspomnianej techniki jest jednolita wysokość elementów wypukłych na całym obrazku dotykowym.

Uczeń nabywający umiejętności korzystania z tyflografiki powinien mieć możliwość zapoznawania się ze zróżnicowanymi technikami ich tworzenia. W różnych okolicznościach pozaszkolnych może mieć styczność $\mathrm{z}$ materiałami formowanymi w inny sposób niż w książkach szkolnych (mapy i plany). Tymczasem podręcznik szkolny, zwłaszcza dla uczniów w szkolnictwie integracyjnym i inkluzyjnym, jest podstawowym nośnikiem wiedzy nie tylko o konwencjach rysunkowych, ale także o sposobach przygotowania tyflografik i wynikających z nich różnicach doświadczania grafiki dotykowej. Podręczniki szkolne powinny więc oferować uczniowi dostęp do reprezentacji dotykowych tworzonych w różnych technikach.

Grafika dotykowa może być efektywniej wykorzystywana przez uczniów, jeśli będzie zawierać dodatkowy komentarz objaśniający.

Komentarz słowny towarzyszący zapoznawaniu się z obiektami rzeczywistymi oraz reprezentacjami dotykowymi ułatwia osobom niewidomym zrozumienie treści przedstawień (Carver i in. 2012, Więckowska 2012, Zebehazy, Wilton 2014). W badaniach Zebehazy'ego i Wiltona (2014) 92\% uczniów niewidomych wskazało, że przydatny w wykorzystywaniu grafiki dotykowej jest dodatkowy opis słowny ( $37 \%$ stwierdziło, że woli opis słowny zamiast grafiki dotykowej). Carver i inni (2012) stwierdzają, że uczniowie wykazują silne preferencje dla opisów oraz są w stanie prawidłowo wykonywać zadania i odpowiadać poprawnie na pytania nawet jeśli dysponują tylko opisem, bez grafiki dotykowej. Jak podkreśla s. E. Więckowska (2012) niekiedy grafice dotykowej powinien towarzyszyć tekst objaśniający, w którym określony zostanie sposób czytania oraz podane będą dodatkowe szczegóły reprezentacji graficznej nieuwzględnione na rysunku wypukłym. Ta praktyka nie zawsze jest wykorzystywana w polskich adaptacjach, w tych sytuacjach, w których byłoby to szczególnie zasadne. Taka strategia mogłaby być pomocna w edukacji integracyjnej i inkluzyjnej uczniów niewidomych, z uwagi na często niepełne przygotowanie mery toryczno-metodyczne nauczyciela w zakresie nauczania uczniów z dysfunkcją wzroku. W takich okolicznościach zwłaszcza propozycje metodyczne mogłyby być szczególnie użyteczne. 
Istnieje potrzeba opracowania standardów dla opisów słownych zastępujących reprezentacje graficzne wizualnych dzieł sztuki.

Współczesne podręczniki dla dzieci niewidomych zawierają interesujące przykłady deskrypcji wizualnych dzieł sztuki, które można niekiedy ująć w ramy przekładu intersemiotycznego (nie tylko prostego opisu, ale podjęcia próby transpozycji sensu i idei zawartych $\mathrm{w}$ oryginalnym przekazie, dzięki poszukiwaniu ekwiwalentnych pozawzrokowych sposobów wyrażania) (Śmiechowska-Petrovskij, w druku).

Mimo to, wciąż ten obszar ingerencji adaptatorów w treść brajlowskich podręczników wymaga dodatkowych instrukcji. Podstawowym dylematem związanym z opisami dzieł sztuki w podręcznikach jest określenie zakresu informacji, które powinny zostać uczniowi przekazane, oraz kwestia interpretacji dzieła poprzez dodane komentarze.

Teksty opisujące wizualne dzieła sztuki powinny prezentować to, co widoczne na obrazie, uwzględniając wymagania stawiane uczniowi w poleceniach do ćwiczeń, bez sugestii, jak interpretować obraz. Istotne jest, by opisy nie były zbyt długie, bowiem pełnią inną funkcję niż deskrypcje dzieł plastycznych oferowane w muzeach i innych instytucjach kultury (te drugie zawierają zazwyczaj zarówno informacje o samym dziele - autorze, technice, prądzie artystycznym, w ramach którego powstało, tematyce, kontekście jego stworzenia i recepcji, jak również o elementach składowych dzieła i ich cechach wizualnych). Nauczyciele zwracają uwagę na fakt, że uczeń niewidomy często otrzymuje o wiele więcej informacji o dziele plastycznym niż jego widzący rówieśnik, co niekiedy prowadzi do uczniowskiej frustracji (żmudne zapoznawanie się z długim opisem, podczas gdy uczniowi widzącemu wystarczy rzut oka i odczytanie podpisu).

Formuła przyjęta w polskich podręcznikach brajlowskich zakłada możliwie najkrótszą formę opisu dzieła sztuki w odniesieniu do tych jego aspektów, które są najistotniejsze z punktu widzenia wykonania zadania. Jest to zasadne założenie, zwłaszcza, że w razie potrzeby nauczyciel może wykorzystać dłuższe opisy dzieł sztuki, które są oferowane w innych źródłach. Bywa jednak także, że ten sam opis danego obiektu graficznego, np. obrazu, jest stosowany w różnych podręcznikach w zróżnicowanych kontekstach treściowych ( $\mathrm{z}$ inną obudową $\mathrm{w}$ postaci poleceń). W takich sytuacjach opis powinien być aktualizowany do bieżących potrzeb.

Konstruując opisy do dzieł plastycznych, deskryptorzy powinni ponadto zwracać szczególną uwagę na następujące kwestie:

- podawanie wszystkich informacji o elementach znajdujących się na obrazie, które są niezbędne do poprawnego wykonania zadań;

- operowanie słownictwem odpowiadającym pod względem pojęciowym i erudycyjnym poziomowi ucznia na danym etapie edukacyjnym;

- niestosowanie opisu odwołującego się do właściwości wzrokowego spostrzegania, bez formułowania dodatkowych objaśnień;

- formułowanie opisu bez elementów interpretacji dzieła oraz subiektywnych ocen i opinii.

Powyższe postulaty wynikają z weryfikacji podręczników brajlowskich, w których niekiedy niezbędna była korekta deskrypcji dzieł plastycznych. Przykładem opisu wymagającego modyfikacji przed zatwierdzeniem podręcznika do użytku był np. następujący opis: 
Artysta ukazał głęboko wzruszającą scenę powitania syna marnotrawnego przez miłosiernego ojca. Wynędzniały młodzieniec w podartych łachmanach klęczy na ziemi, tyłem do widza, w postawie pełnej pokory. Jego stary ojciec pochyla się nad nim i przytula go z miłością. Scenie tej przygląda się kilku mężczyzn, z których jeden, bogato ubrany, wydaje się być starszym bratem powracającego. Jego twarz wyraża zdziwienie i niezadowolenie. Dzieło utrzymane jest w tonacji czerwieni i brązów, zaś malarz w mistrzowski sposób operuje światłem ${ }^{5}$.

Przytoczony tekst zawiera elementy oceny i wyraża subiektywne odczucia związane $z$ odbiorem dzieła. Nie informuje również ucznia o relacjach przestrzennych między obiektami przedstawionymi na obrazie (nie wiadomo, kto i gdzie się znajduje). Określenie „malarz w mistrzowski sposób operuje światłem” nie dostarcza uczniowi merytorycznej wiedzy. Zamiast takiego określenia można wskazać, na czym polega operowanie światłem - najbardziej oświetlony jest ojciec i syn marnotrawny, słabiej brat, w cieniu pozostają dwie postacie. Zadaniem ucznia jest, między innymi, udzielenie odpowiedzi, co znajduje się na pierwszym i drugim planie oraz w tle obrazu. Opis dzieła nie niesie tych informacji.

Opracowania standardów dla opisów słownych zastępujących reprezentacje graficzne wizualnych dzieł sztuki mogłoby przyczynić się do efektywniejszej pracy ucznia z tą formą adaptacji grafiki.

\section{Podsumowanie}

Współczesny podręcznik brajlowski dla ucznia niewidomego jest środkiem dydaktycznym dostarczającym nie tylko wiedzy przedmiotowej oraz umożliwiającym ćwiczenie umiejętności przewidzianych programem nauczania, ale także informacji o wizualnych środkach przedstawiania i może wspierać edukację tyflograficzną ucznia poprzez oferowanie wiedzy o różnych konwencjach rysunkowych oraz zróżnicowanych technikach ich tworzenia W ten sposób jest materiałem kształcącym kompetencje ucznia w zakresie graphicacy, jak również ułatwiającym pełniejsze włączenie do grupy uczniów bez dysfunkcji. Aby jednak wszystkie wymienione procesy były efektywne, niezbędna jest dbałość o różnorodne elementy strukturalne podręczników adaptowanych do potrzeb uczniów niewidomych. Podsumowując zaprezentowane uprzednio analizy, należy wskazać, iż $\mathrm{w}$ procesie doskonalenia podręcznika jako środka dydaktyczno-rewalidacyjnego oraz medium społeczno-kulturowego, zasadne jest:

- prowadzenie badań nad czytelnością dotykową wypukłych grafik zastosowanych w podręcznikach na grupie uczniów niewidomych, którzy są odbiorcami treści;

- proponowanie grafik dotykowych wykonanych w zróżnicowanych technikach, które będą najlepsze dla danego typu prezentacji;

- konstruowanie opisów reprezentacji graficznych z uwzględnieniem słownictwa adekwatnego do poziomu edukacyjnego ucznia oraz celu, któremu ma służyć zapoznanie się z grafiką;

\footnotetext{
${ }^{5}$ Opis obrazu Rembrandta Powrót syna marnotrawnego z brajlowskiej adaptacji podręcznika (przed weryfikacją ekspercką) Bliżej słowa. Język polski, klasa 2 gimnazjum, E. Horwath, G. Kiełb, WSiP 2011.
} 
- w uzasadnionych przypadkach: uzupełnianie grafik dotykowych dodatkowym opisem objaśniającym optymalny sposób zapoznawania się z grafiką wypukłą oraz dostarczającym dodatkowej wiedzy o szczegółach oryginalnego obrazka.

Oprócz powyżej zarysowanych postulatów, warto również rozważyć włączenie do refleksji pedagogicznej wątków uwzględniających perspektywę analityczno-dyskursywną oceny podręczników. Czy takie analizy w ogóle mogą być produktywne w odniesieniu do materiałów brajlowskich? Choć kwestia ta wymaga dyskusji, można wstępnie wyznaczyć potencjalne obszary takich analiz, np. namysł nad motywami leżącymi u podstaw wybierania konkretnych podręczników przez nauczycieli do adaptacji dla uczniów niewidomych (określenia, czy motywy odnoszą się do kwestii lepszej dostępności treści, czy konkretnego, tzn. preferowanego obrazowania rzeczywistości kulturowo-społecznej?), a także badanie deskrypcji wizualnych przedstawień zawartych w podręcznikach szkolnych (czy ukierunkowane są na przekaz informacyjny, czy również odnoszą się do kształtowania sfery etycznej i estetycznej ucznia?).

Powyżej zarysowane pola analiz prowadzą do wniosku, że adaptacja podręczników szkolnych do potrzeb uczniów niewidomych, jako obszar problemowy badań pedagogicznych, wymaga wciąż teoretycznych i empirycznych weryfikacji.

\section{Bibliografia}

Aldrich, F., Sheppard, L. (2000). Graphicacy; The fourth 'R'? „Primary Science Review”, nr 64, s. 8-11.

Bendych E. (1994). Badania nad rysunkiem niewidomego dziecka. Cz. 1. „Szkoła Specjalna”, nr 5, s. 276-287.

Bendych E. (1995). Badania nad rysunkiem niewidomego dziecka. Cz. 2. „Szkoła Specjalna”, nr 3, s. 141-153.

Carver W., Howell J. J., Ferrell K. A. i in. (2012). Description enhanced assessment forstudents with visual and print disabilities [Final Report, Grant \#S368Ao90o19, U. S. Department of Education]. Salt Lake City, UT: Utah State Office of Education.

Chojecka A., Magner M., Szwedowska E., Więckowska E. (2008). Nauczanie niewidomychdzieci rysunku. Laski: Towarzystwo Opieki Nad Ociemniałymi.

Chojecka A., Hermanowicz B., Fuksiński C., Mendruń J., Olczyk M., Rudnicka M., Więckowska E. (2012). Standardy tworzenia oraz adaptowania map $i$ atlasów dla niewidomych uczniów. Redagowane przez s. E. Więckowską, dostępne na: http://tyflomapy. pl/Standardy_tworzenia_oraz_adaptowania_map_i_atlasow_.html (otwarty 12.01.2015).

Czerwińska K. (2006). Możliwości wykorzystania grafiki dotykowej w nauczaniu języków obcych - teoria a praktyka. „Szkoła Specjalna”, nr 5, s. 323-329.

Czerwińska K. (red.). (2008a). Adaptacja pomocy w nauce języków obcych osób niewidomych i słabo widzacych. Warszawa: Wyd. APS.

Czerwińska K. (2008b). Języki obce a osoby z dysfunkcja wzroku. Warszawa: Wyd. APS.

Czerwińska K. (2008c). Rysunek wypukły, jako pomoc dydaktyczna w nauczaniu języków obcych - doniesienia z badań. W: Czerwińska K. (red.). Adaptacja pomocy w nauce języków obcych osób niewidomych i słabo widzących. Warszawa: Wyd. APS. 
Dłuska J., Karwowska M., Karasińska W. (red.). (2011). Świat w zasięgu ręki. Dobre praktyki - projekt „Bliżej świata - od konkretu do abstrakcji”. Bydgoszcz: Wyd. SOSW Nr 1 dla Dzieci i Młodzieży Słabo Widzącej i Niewidomej im. L. Braille’a.

Dziewulak D. (2012). Dostęp do podręczników dla dzieci niewidomych i słabowidzących w Polsce, Szwecji i Wielkiej Brytanii. „Analizy BAS”, nr 8(75), s. 1-8.

Gajdzica Z. (2014a). Podręczniki w tradycyjnie ujętym procesie kształcenia uczniów z lekka niepetnosprawnościa intelektualna - na marginesie dyskusji o nowym powszechnym i jednolitym elementarzu. „Szkoła Specjalna”, nr 4, s. 277-284.

Gajdzica Z. (2014b). Jaki podręcznik dla ucznia ze specjalnymi potrzebami edukacyjnymi? Kilka uwag na marginesie dyskusji medialnej o nowym, darmowym i powszechnym podręczniku. „Wychowanie na co dzień” (w druku).

Instrukcja tworzenia i adaptowania ilustracji i materiałów tyflograficznych dla uczniów niewidomych. (2011). Opracowana na zlecenie Departamentu Zwiększania Szans Edukacyjnych Ministerstwa Edukacji Narodowej przez zespół tyflopedagogów ze Specjalnych Ośrodków Szkolno-Wychowawczych w Polsce, redagowane przez s. E. Więckowską. Bydgoszcz, Kraków, Laski, Owińska (brak wydawnictwa).

Jakubowski M. (2009). Tyflografika - historia i współczesność, metody i technologie. "Tyfloświat”, nr 1(3), s. 36-40.

Kauba K. (red.). (2011). Brajlowska notacja matematyczna fizyczna chemiczna. Wyd. II. Kraków, Laski, Łódź (brak wydawnictwa).

Kończyk D. (red.). (2011). Zasady adaptacji materiałów dydaktycznych do potrzeb osób słabowidzacych. Warszawa: Biuro ds. Osób Niepełnosprawnych Uniwersytetu Warszawskiego.

Kuczyńska-Kwapisz J. (red.). (2012). Współczesna recepcja myśli Matki Elżbiety Róży Czackiej - kształcenie i rehabilitacja. Warszawa: Wyd. UKSW.

Kuczyńska-Kwapisz J. (red.). (2012). Współczesna recepcja myśli Matki Elżbiety Róży Czackiej - wychowanie. Warszawa: Wyd. UKSW.

Kuczyńska-Kwapisz J., Wałachowska M. (200oa). Podręczniki szkolne dla uczniów niewidomych. Wyniki badań międzynarodowych. Cz. 1. „Szkoła Specjalna”, nr 2-3, s. 83-90.

Kuczyńska-Kwapisz J., Wałachowska M. (200ob). Podręczniki szkolne dla uczniów niewidomych. Wyniki badań międzynarodowych. Cz. 2. „Szkoła Specjalna”, nr 4, s. 164-172.

Matys M. (2008). Tyflografika. „Tyfloświat”, nr 1(1), s. 36-39.

O'Day A. R. (2014). Proofreading the tactile graphic: the important last step. "Journal of Blindness Innovation and Research", nr 4(1), dostępny na: https://nfb.org/images/nfb/ publications/jbir/jbir14/jbiro40103.html, doi: http://dx.doi.org/10.5241/4-59 (otwarty 11.01.2015).

Paplińska M. (red.). (2012). Jak przygotować niewidome dziecko do nauki brajla. Przewodnik dla rodziców i nauczycieli. Warszawa: Trakt.

Poppe K.J. (2006). Tactile graphic methods. American Printing House for the Blind, dostępny na: http://www.aph.org/videos/atc2008/ppt/3/tgm.doc (otwarty 11.01.2015).

Śmiechowska-Petrovskij E. (2010). Adaptacja podręczników do potrzeb uczniów niewidomych. „Nasze Dzieci”, nr 1, s. 31-46.

Śmiechowska-Petrovskij E. (w druku). Przekład intersemiotyczny w procesie wprowadzania niewidomego dziecka $w$ świat kultury. Referat wygłoszony na ogólnopolskiej konferencji naukowej „Osoba z niepełnosprawnością w drodze (na drodze) ku...” 
zorganizowanej przez Uniwersytet Warmińsko-Mazurski, w dniach 20-21 października 2014 r. w Olsztynie.

Talukder A. (2010). Życie dziecka bez obrazków. „Tyfloświat”, nr 1(7), s. 21-26.

Wdówik P. (2011). Zasady adaptacji materiałów dydaktycznych do wersji brajlowskiej. Warszawa: Biuro ds. Osób Niepełnosprawnych Uniwersytetu Warszawskiego.

Więckowska E. (2012). Polska szkoła tyflografiki. „Niepełnosprawność. Półrocznik naukowy", nr 7, s. 55-80.

Witczak-Nowotna J. (red.). (2010). Wspomaganie uczniów z dysfunkcją wzroku w szkołach ogólnodostępnych. Wybrane zagadnienia. Warszawa: Biuro ds. Osób Niepełnosprawnych Uniwersytetu Warszawskiego.

Zalewska E. (2009). Teoretyczne i metodologiczne konteksty badań nad podręcznikiem szkolnym w Niemczech: między ujęciem konwencjonalnym a dyskursywno-analitycznym. W: Hurło L., Klus-Stańska D., Łojko M. (red.). Paradygmaty współczesnej dydaktyki. Kraków: Impuls.

Zalewska E. (2012). Programy kształcenia i podręczniki szkolne w edukacji poczatkowej jako „wybór z kultury”. W: Klus-Stańska D., Szczepska-Pustkowska M. (red.). Pedagogika wczesnoszkolna - dyskursy, problemy, rozwiązania. Warszawa: Oficyna Wydawnicza Łośgraf.

Zasady tworzenia i adaptowania grafiki dla uczniów niewidomych. (2011). Opracowane przez nauczycieli Specjalnych Ośrodków Szkolno-Wychowawczych dla Niewidomych i Słabo Widzących w Polsce. Bydgoszcz, Laski, Łódź (brak wydawnictwa).

Zebehazy, K.T., Wilton, A.P. (2014). Straight from the Source: Perceptions of students with visual impairments about graphic use. „Journal of Visual Impairment and Blindness”, 108(4), s. 275-286.

Żabińska A. (2011). Praca z młodzieża niewidoma i słabowidząca. Metoda pracy sekwencjami na lekcjach plastyki. Warszawa: Difin.

\section{SCHOOL TEXTBOOKS ADAPTATION FOR BLIND STUDENTS \\ - CURRENT SITUATION AND SCIENTIFIC AS WELL AS PRACTICAL DEMANDS}

Abstract: The article discusses the issue of school textbooks adaptation to the needs of blind students in Polish educational system. It defines the concept of adaptation and presents standards of creation Braille textbooks as well as adaptation policy. The article shows also the main principles of adaptation concerning text formatting and graphic representations. Moreover, based on the analysis of adaptation of school textbooks to the Braille system, there are theses formulated on the current situation of Braille textbooks adaptation in Poland and scientific as well as practical demands in this area.

Key words: blind children, Braille system, textbooks adaptation for blind people, tactile graphic, textbooks

Emilia Śmiechowska-Petrovskij - doktor nauk społecznych w dyscyplinie pedagogika, pedagog specjalny (tyflopedagog) i filolog polski, adiunkt w Katedrze Pedagogiki Specjalnej i Integracyjnej Wydziału Nauk Pedagogicznych UKSW, ekspert Ośrodka Rozwoju Edukacji ds. weryfikacji podręczników i książek pomocniczych w brajlu i powiększonym druku. Adres do korespondencji: Wydział Nauk Pedagogicznych, ul. Wóycickiego 1/3, 01-938 Warszawa. Adres e-mail: e.smiechowska@uksw.edu.pl 